\title{
MAUSU'AH WA MAFHUMUL HADIS BAN RIBA TRANSACTIONS IN MUSNAD AHMAD
}

\author{
Nurhadi \\ Islamic College (STAI) Al-Azhar Pekanbaru Riau \\ Email: alhadijurnal@gmail.com; alhadicentre@yahoo.co.id
}

\begin{abstract}
Islam is a comprehensive religion that encapsulates all human life including economic activities. This era of modern and sophisticated times, the phenomenon of the development of existing business activities must be vigilant, so as not to fall prey to usury. Then what about the hadith in Ahmad's musnad relating to usury?. The results of the author's research in the book mausu'ah alhadis al-Nabawiyah, from the hadith perspective in the book Musnad Ahmad. Then found 6 traditions related to usury property. The hadith is No. Hadith 803 in the Book: Musnad of ten companions guaranteed to enter heaven, Chapter: Musnad Ali bin Abu Talib Radliyallahu 'anhu. Hadith No. 1222 in the Book: Musnad of ten companions who are guaranteed to enter heaven, Chapter: Musnad Ali bin Abu Talib Radliyallahu 'anhu. Hadith No. 1294 in the Book: Musnad of ten companions guaranteed to enter heaven, Chapter: Musnad Ali bin Abu Talib Radliyallahu 'anhu. Hadith No. 3539 in the Book: Musnad companions who have narrated many hadith, Chapter: Musnad Abdullah bin Mas'ud Radliyallahu ta'ala 'anhu. Hadith No. 3567 in the Book: Musnad friends who have narrated many hadith, Chapter: Musnad Abdullah bin Mas'ud Radliyallahu ta'ala 'anhu. Hadith No. 13744 in Ahmad Musnad, it will appear in the Book: Remaining Musnad companions who have narrated many hadith, Chapter: Musnad Jabir bin Abdullah Radliallahu ta'ala 'anhu. So from the hadith it can be drawn the understanding that Allah cursed the eaters of usury, the person who gave food with usury, the witness of the usury contract and the person who wrote it. Even though a lot of usury will eventually be a little.
\end{abstract}

Keywords: Mausu'ah, Mafhum, Hadits, Prohibitions, Riba Transactions.

\section{Introduction}

Islam is a comprehensive religion that encapsulates all human life including economic activities. The overall implementation of Islam will bring blessings to all the world, including humans who carry out economic activities. ${ }^{1}$ This era of modern and sophisticated times the development of the economic system has been very rapid. Various systems offered by businessmen to compete attract the hearts of customers. A Muslim economy that is not only oriented to the benefits of the world, it should be clever, also always analyze the

${ }^{1}$ Boy Syamsul Bakhri, Islamic Economic System in Comparison (Al-Hikmah Journal Vol. 8, No. 1, April, 2011, ISSN 1412-5382), p. 48-49 
phenomenon of the development of existing business activities, in order to know the views of the Shari'a on a business transaction, so as not to fall into His prohibition (usury). ${ }^{2}$

The business activities of the economy that are loved by most people are the sale and purchase of credit. One transaction that is fast getting goods and profits is buying and selling credit. Among the sale and purchase agreements that are prohibited with violent violations include Riba. In Islam, picking usury or making a profit in the form of usury loans is unlawful. This is confirmed in the Qur'an of Surah al-Baqarah verse 275:

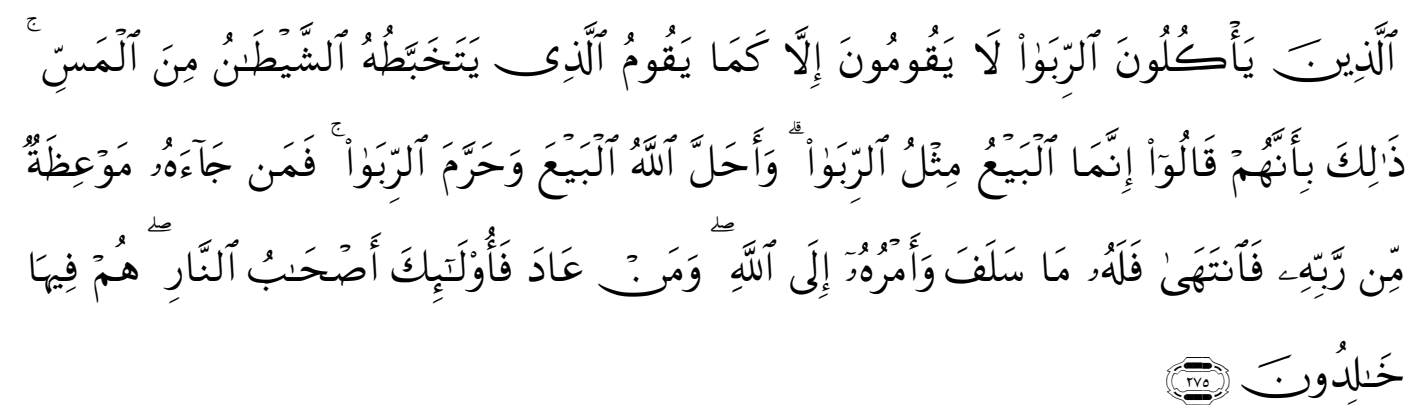

Meaning: People who eat (take) usury (usury is of two kinds: nasiah and fadhl. Usury nasiah is more payment required by people who lend. Usury fadhl is the exchange of goods with similar goods, but more in number because the person exchanging requires such things, such as the exchange of gold with gold, rice with rice, etc. usury referred to in this verse double usury nasiah which is common in the Jahiliyah Arab society) cannot stand but like the establishment of people who are possessed of satan because of (pressure) madness (meaning: the person who takes usury does not restrain his soul like a conqueror.). this condition is due to their saying (opinion), Indeed, buying and selling is the same as usury, even though Allah has justified buying and selling and prohibiting usury. those who have reached him a ban from his Lord, then continue to stop (from taking usury), so for him what he has taken before (usury that has been taken (collected) before going down this verse, may not be returned) (before the prohibition comes); and his business (up to God). the person who returns (takes usury), then that person is the inhabitants of hell; they abide therein. $^{3}$

\footnotetext{
${ }^{2}$ Muslims, Shari'ah Review of Credit Purchases, see wibesite online https://muslim.or.id/20961-view-syari-terhadap-jual-beli-kredit.html. Accessed on September 20, 2018

${ }^{3}$ RI Ministry of Religion, Al-Qur'an and Translation (Semarang: Toha Putra, 2015), p. 69
} 
In addition to the Word of Allah SWT above, it also becomes a proposition about usury, found in Surah al-Imran verse 130 as follows:

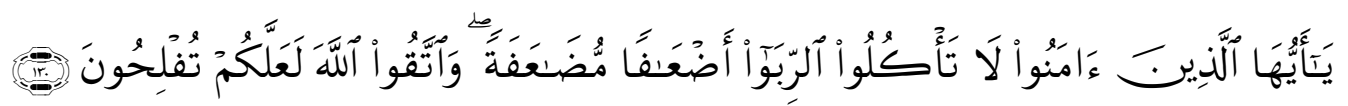

Meaning: $O$ ye who believe, do not eat usury with multiples (what is meant by usury here is usury nasi'ah. According to most scholars that usury nasi'ah is forever Haram, although not multiplied. Riba is two kinds: nasiah and fadhl. usury nasiah is more payments required by people who lend. usury fadhl is the exchange of goods with similar goods, but more in number because people who exchange require such, such as exchanging gold with gold, rice with rice, and so on, usury referred to in this verse double usury of nasiah which is common in Arabian Jahiliyah societies) and fear Allah for you to have good luck. ${ }^{4}$

In surah al-Baqarah verse 276 as follows:

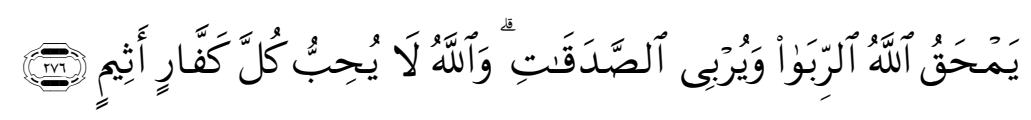

Meaning: Allah destroys usury and fertilizes alms (what is meant by annihilating usury is to destroy the property or negate his blessing, and what is meant by fertilizing alms is to develop the treasure which has been given out or to multiply the blessing). and God does not like anyone who remains in disbelief, and always sins (meaning those who justify usury and keep doing it). ${ }^{5}$

In surah al-Baqarah verses 278-279 as follows:

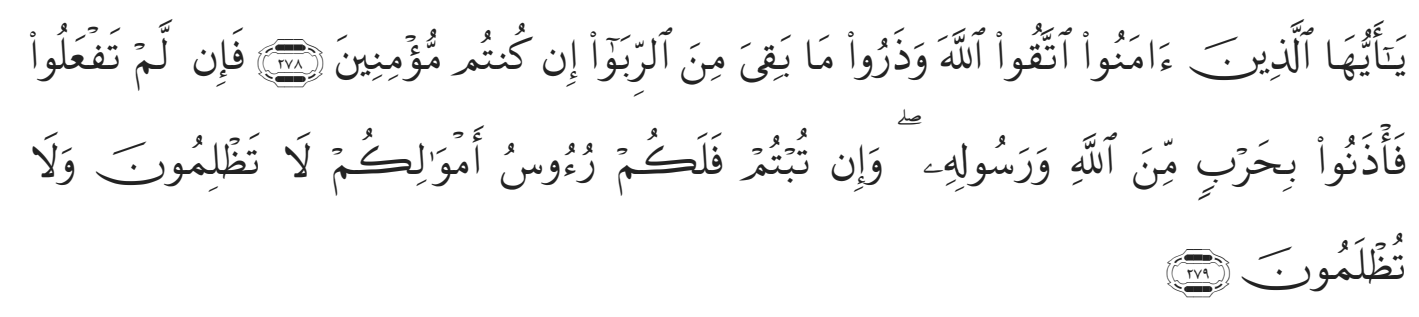

Meaning: $O$ ye who believe, fear Allah and leave the rest of usury (which has not been collected) if you are believers. So if you do not do (leave the rest of usury), then Know, that Allah and His messenger will fight you. and if you repent (from taking usury), then for you the treasure; You do not persecute and are not persecuted. ${ }^{6}$

And among the traditions associated with usury are:

\footnotetext{
${ }^{4}$ Ministry of Religion of the Republic of Indonesia, Al-Qur'an and Translation, p. 97

${ }^{5}$ Ministry of Religion of the Republic of Indonesia, Al-Qur'an and Translation, p. 69

${ }^{6}$ Ministry of Religion of the Republic of Indonesia, Al-Qur'an and Translation, p. 69-70
} 


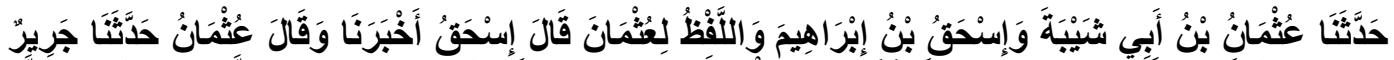

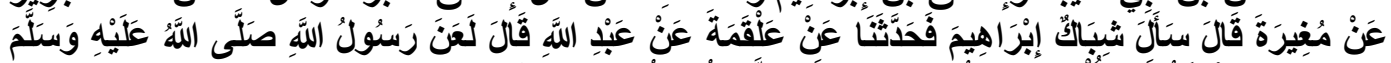

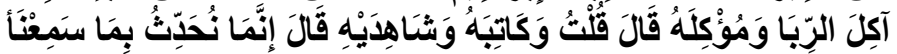

Meaning: Has told us Uthman ibn Abu Syaibah and Ishaq bin Ibrahim and this is lafadz Uthman. Ishaq said; had told us, and Uthman said; had told us Jarir from Mughirah he said, "Syibak asked Ibrahim, then he told us from 'Alqamah from Abdullah he said," the Prophet sallallaahu' alaihi wasallam cursed the person who ate the results of usury and who told him to eat it. "'Alqamah said "I asked," (What about) the secretary of the usury certificate maker and his witnesses?" he replied, "We only tell from something we heard." (Narrated by Muslim). ${ }^{7}$

Through the verses and hadith above, so in detail the traditions of usury in the book of hadith are the main reference after the quran. So in this research paper will discuss the text of the Prophet's hadith texts in the issue of usury in the hadith of Ahmad bin Hambal's hadith.

\section{Biography of Imam Ahmad bin Hambal}

Ahmad bin Muhammad ibn Hanbal al-Syaibany was born in Baghdad precisely in the City of Maru / Merv, in the month of Rabi'ul early in the year 164 $\mathrm{H}$ or November 780 AD His full name is Ahmad ibn Muhammad ibn Hanbal ibn Hilal ibn Asad ibn Idris abn 'Abdillah bin Hayyan ibn 'Bdillah bin Anas ibn' Awf ibn Qasit bin Mazin ibn Syaiban ibn Zual ibn Ismail ibn Ibrahim. ${ }^{8}$

When Ahmad was a child, his father passed away to Allah Almighty by leaving only mediocre assets to support his family. A narration states that, if Ahmad ibn Hanbal was asked about the origin of his tribe, he said that he was a child of a tribe of poor people. He lives as a commoner, lives in their midst and feels suffering, their wounds and grief. ${ }^{9}$ Such conditions become one of the drivers for Ahmad to study sincerely. He wanted to immediately reduce the

\footnotetext{
${ }^{7}$ Abul Husain Muslim bin al-Hajjaj al-Naisaburi, Muslim Imam, Shahih Muslim (Beirut: Dar Ibn Kathir, t.th), no hadis. 2994

${ }^{8}$ Ibn Jauzi, I'lamu al-Muaqqi'in, (Riyadh: Maktabh sunnah, t.th), p. 177-358; Ahmad Muhammad bin Kasir, Tafisr Ibn Kasir, (Cairo: Maktbah ilmiyah, t.th), p. 325-342

${ }^{9}$ Ziaul Haque, Wahyu and Revolusi, (Yogyakarta: LKIS, 2012), p. 96
} 
burden on his mother. He also saw the number of bid'ah spread in the community. It was also this that encouraged him to go to various regions in search of hadith. ${ }^{10}$

Ahmad is married and has two famous sons in the field of hadith namely Salih and Abdullah. His two sons received many hadiths from his father and included a number of traditions in his father's Musnad book. Imam Ahmad ibn Hanbal is a picture of a character who is simple, populist and has a high Islamic commitment. His love for hadith and loyalty to the Prophet which must be paid for by physical and non-physical sacrifice, is an added value that must be appreciated. $^{11}$

In $195 \mathrm{H}$ to $197 \mathrm{H}$ Ahmad studied fiqh and Ushul Fiqh on Imam Shafi'i who at that time was in the hijaz. In Hijaz he also studied with Imam Malik and Imam al-Laitsbin Sa'ad al-Misri. In the search for hadith he also went to Yemen and other areas, such as Khurasan, Persia, and Tarsus. ${ }^{12}$

A book is called the book Musnad if the compiler includes all the hadiths that he has received, without filtering and explaining the degrees of the traditions.. ${ }^{13}$ Another understanding of the book of Musnad is the book in which the traditions in it are mentioned based on the name of a friend who first converted to Islam or based on nasab. Judging from the value of the hadith in the book, according to scholars, the degree of this book is under the book Sunan. Subhi al-Salih placed Musnad Ahmad in the second rank equal to Jami 'alTarmizi and Sunan Abu Dawud. ${ }^{14}$

Musnad Ahmad included the most famous and largest book compiled in the fifth period of the development of hadith. This book completes and collects the books of hadith that existed before and is a book that can meet the needs of Muslims in terms of religion and the world in his time. The hadiths contained in the Musnad were mentioned not all of Ahmad's history, some of them were in

\footnotetext{
${ }^{10}$ Mustafa Hamdu 'ullayan Al-Hambali, Between the Hambali School and Contemporary Salafi, (Jakarta: Al-Kausar Library, 2018), p. 18

${ }^{11}$ Mustafa Hamdu 'ullayan Al-Hambali, Between the Hambali School and Contemporary Salafi, p. 19

${ }^{12}$ Mustafa Hamdu 'ullayan Al-Hambali, Between the Hambali School and Contemporary Salafi, p.. 20

${ }^{13}$ T.M. Hasbi Ash-Shiddieqy, Al-Islam, (Bulan Bintang, Jakarta, 2015), p. 104.

${ }^{14}$ T.M. Hasbi Ash-Shiddieqy, Al-Islam, p. 104
} 
addition to his son named Abdullah and an addition from Abu Bakar al-Qati'i. ${ }^{15}$ The Musnad contains 40,000 traditions. Addition of Abdullah about 10,000 hadiths and a few additional ones from Ahmad bin Ja'far al-Qatili. Abdullah ibn Ahmad ibn Hanballah who compiled the Book of Musnad. ${ }^{16}$

\section{The Concept of Riba in Islam}

Basically, usury transactions can occur from accounts payable transactions, but the form of the source can be qard, Qard comes from the word - wرض يقرض قضضر - which means loan, ${ }^{17}$ according to Abdurrahman al-Jaziri, qard is a property taken by someone who borrows because the person who borrowed it was cutting off his property, ${ }^{18}$ buyu ', According to Abdullah al-Mushlih and Shalah ash-Shawi buying and selling are two words that contradict each other, but each is often used for the meaning of other words alternately. Therefore, each in the transaction agreement is referred to as the buyer and seller. Rasulullah saw. He said, "two people who sell and buy have the right to make a choice, before they move from the location of buying and selling." But if it is mentioned in general, what lies in the right is that the word seller is intended for people who issue merchandise. While buyers are people who pay fees. The seller is the one who issued his property. While the buyer is the person who makes the item his own with the condition of payment compensation. ${ }^{19}$ According to Chairuman Pasaribu and Suhrawardi K. Lubis: The word buying and selling consists of two syllables, namely buying and selling. Actually the words "sell" and "buy" have the meaning of each other opposite and so on. ${ }^{20}$ The scholars determined firmly and clearly about the prohibition of usury, because usury contained an element of exploitation

\footnotetext{
${ }^{15}$ Mustafa Hamdu 'ullayan Al-Hambali, Between the Hambali School and Contemporary Salafi, p.. 31 Salafi, p. 31

${ }^{16}$ Mustafa Hamdu 'ullayan Al-Hambali, Between the Hambali School and Contemporary

${ }^{17}$ Ahmad Munawir, Dictionary of al-Munawir Arabic-Indonesian, (Yogyakarta: PP. AlMunawwir, 2013), p. 1108

${ }^{18}$ Abdurrahman al-Jaziri, Kitab al-figh 'ala al-Mazahib al-Arba'ah, (Beirut: dar al-Fikr, 2012), p. 338

${ }^{19}$ Abdullah al-Mushlih and Shalah ash-Shawi, Jurisprudence in Islamic Financial Economics (Jakarta: Darul Haq, 2014), p. 89-90

${ }^{20}$ Chairuman Pasaribu and Suhrawardi K. Lubis, Agreement Law in Islam, (Jakarta: Sinar Grafika, 2014), p. 33
} 
whose impact was detrimental to others, this refers to the Kitabullah and the Sunnah of the Apostles and the ijma 'of the scholars. It can even be said that the prohibition has become an axiom in Islamic teachings. ${ }^{21}$ The word riba comes from Arabic, etymologically means extra (azziyadah), ${ }^{22}$ developing (an-numuw), enlarging (al-'uluw), according to Shaykh Abul A'la al-Maududi An-Numuw is growth and Al-'Uluw is high. and increase (al-irtifa '). ${ }^{23}$ In relation to the meaning of usury in terms of the language, there are expressions of ancient Arabs stated as follows; arba fulan 'ala fulan idza azada' alaihi (a person commits usury towards others if there is an additional element or is called liyarbu ma a'thaythum min syai'in lita'khuzu aktsara minhu (taking from something that you give in an excessive way than what which is given). ${ }^{24}$

\section{Methodology}

This type of research is included in qualitative research, because the nature of the data to be collected is qualitative. ${ }^{25}$ Therefore research data is naturalist by using inductive logic and reporting is descriptive. ${ }^{26}$ This research focuses on library research or text studies. ${ }^{27}$ So this study will focus more on the studies of the text, and include the type of qualitative research. ${ }^{28}$ Library research is done because the data sources, both primary (resources) and supporters (secondary

\footnotetext{
${ }^{21}$ Abdullah al-Mushlih and Shalah ash-Shawi, Islamic Financial Economics Jurisprudence, p. 345

${ }^{22}$ Abu Sura'i Abdul Hadi, Bunga Bank In Islam, translate M. Thalib, (Surabaya: al-Ikhlas, 2013), p. 125

${ }^{23}$ Abul A'la al-Maududi, Bicara Tentang Bunga Bank dan Riba (Jakarta: Mega Media, 2014), hlm. 110

${ }^{24}$ Khoiruddin Nasution, Riba and Polygamy, A Study of Muhammad Abduh's Thought, (Yogyakarta: Student Library in collaboration with ACAdeMIA, 2016), p. 37

${ }^{25}$ Hadari Nawawi, Social Research Methods, (Yogyakarta: Gajah Mada University Press, 2016); Lexy J. Meleong, Qualitative Research Methods, (Bandung: Youth Rosda Karya, 2011), p. 29

${ }^{26}$ Imam Suprayogo and Tobroni, Social-Religion Research Methodology, (Bandung: Adolescents Rosdakarya, 2012); Bugin Burhan, Qualitative Research; Communication, Economics, Public Policy and Other Social Sciences, (Jakarta: Kencana, 2008), p. 121

${ }^{27}$ Hamidi, Qualitative research method, (Malang: University of Muhammadiyah Malang, 2014); Afrizal, Qualitative Research Method: An Effort to Support the Use of Qualitative Research in Various Disciplines. (Jakarta: Rajawali Press, 2014), p. 21

${ }^{28}$ Muhammad Nazir, Research Methodology, (Jakata: Ghalia Indonesia, 2015); HB Sutopo, Introduction to Qualitative Research, (Surakarta: Sebelas Maret University Press, 2014); Noeng Muhajir, Quantitative Research Methodology, (Yogyakarta: Rake Sarasin, 1996), p. 169
} 
resources) are all text. ${ }^{29}$ In this case the source is the book mausu'ah al-Nabawiyah al-Hadith and their thematic (al-Mausu'ah digital sofwer).

\section{Discussion}

Research of the author in the book mausu'ah al-hadis al-Nabawiyah, from the hadith perspective in the Musnad Ahmad. Then the hadiths related to usury can be found as many as 6 traditions in the book, starting from the hadith number 803 to 13744 . See the table of mausu'ah as follows:

\begin{tabular}{|c|c|c|c|}
\hline No & $\begin{array}{l}\text { Hadith } \\
\text { No. }\end{array}$ & Titles in the Book of Hadith & $\begin{array}{c}\text { Text of the Arabic Text of } \\
\text { the Hadith Book }\end{array}$ \\
\hline 1 & 803 & $\begin{array}{l}\text { Musnad Ali bin Abu Thalib } \\
\text { Radliyallahu 'anhu }\end{array}$ & ونهن مسند علي بن أبي طالب رضي الله \\
\hline 2 & 1222 & $\begin{array}{l}\text { Musnad Ali bin Abu Thalib } \\
\text { Radliyallahu 'anhu }\end{array}$ & ونهن مسند علي بن أبي طالب رضي الله \\
\hline 3 & 1294 & $\begin{array}{l}\text { Musnad Ali bin Abu Thalib } \\
\text { Radliyallahu 'anhu }\end{array}$ & ونه من مسند علي بن أبي طالب رضي الله \\
\hline 4 & 3539 & $\begin{array}{l}\text { Musnad Abdullah bin Mas'ud } \\
\text { Radliyallahu ta'ala 'anhu }\end{array}$ & تعالى عند عبد الله بن مسعود رضي الله \\
\hline 5 & 3567 & $\begin{array}{l}\text { Musnad Abdullah bin Mas'ud } \\
\text { Radliyallahu ta'ala 'anhu }\end{array}$ & تعالى عنده عبد الله بن مسعود رضي الله \\
\hline 6 & 13744 & $\begin{array}{l}\text { Musnad Jabir bin Abdullah } \\
\text { Radliyallahu ta'ala 'anhu }\end{array}$ & عنه جند جابر بن عبد الله رضي الله تعالى \\
\hline
\end{tabular}

If seen from the hadith 803 in the book Musnad Ahmad, it will appear in the Book: Musnad ten companions who are guaranteed to enter heaven, Chapter: Musnad Ali bin Abu Talib Radliyallahu 'anhu, No. Hadist: 803, the hadith as follows:

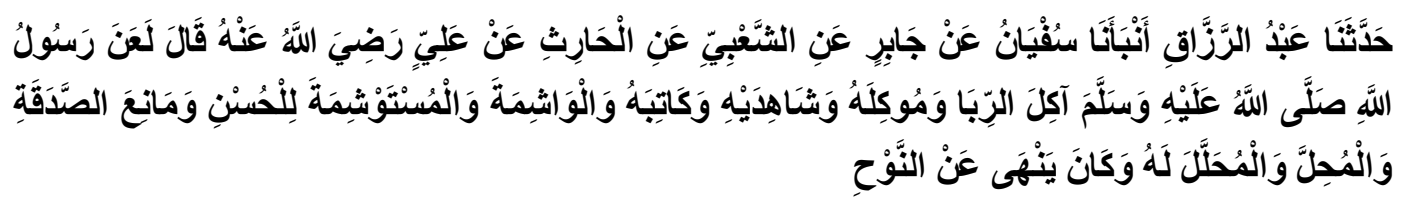

Meaning: Having told us Abdurrazzaq told us Sufyan from Jabir from Ash Sya'bi from Al Harith from Ali Radliallah 'anhu, he said; "The Prophet

${ }^{29}$ Iskandar, Qualitative Research Methods: Applications for Educational Research, Law, Economics \& Management, Social, Humanities, Politics, Religion and Philosophy, (Jakarta: Gaung Persada, 2010); Sugiono, Understanding Qualitative Research, (Bandung: ALFABETA, 2005), p. 329 
sallallaahu alaihi wasallam cursed those who ate usury, people who fed with property of usury, two witnesses, people who tattooed and people asked to be tattooed to look good, people who did not pay zakat, al muhil and al muhallal lahu, and he also forbids mourning corpses. " (Narrated by Ahmad). ${ }^{30}$

Hadith Ahmad No. 803 above is supported by 22 traditions from several histories. See the following table of the verses of the hadith of al-Tis'ah:

\begin{tabular}{|c|c|c|c|c|}
\hline No & $\begin{array}{c}\text { No } \\
\text { Hadith }\end{array}$ & Narrators & $\begin{array}{l}\text { Titles in the Book of } \\
\text { Hadith }\end{array}$ & $\begin{array}{c}\text { Text of the Arabic Text of } \\
\text { the Hadith Book }\end{array}$ \\
\hline 1 & 2994 & Muslim & $\begin{array}{l}\text { Usury eaters and donors } \\
\text { will be cursed }\end{array}$ & لعن آكل الربا ومؤكله \\
\hline 2 & 2995 & Muslim & $\begin{array}{l}\text { Usury eaters and donors } \\
\text { will be cursed }\end{array}$ & لعن آكل الربا ومؤكله \\
\hline 3 & 2895 & Abu Daud & $\begin{array}{l}\text { People who eat usury } \\
\text { and those who give it }\end{array}$ & في آكل الربا وموكله \\
\hline 4 & 1127 & Tirmidzi & Eat usury & ما جاء في أكل الربا \\
\hline 5 & 5013 & Nasa'i & $\begin{array}{l}\text { Mentoring and } \\
\text { differences in Abdullah } \\
\text { bin Murrah and } \\
\text { Asysya'bi }\end{array}$ & الله بن مرة والثُتبـي وذكر الاختلاف على عبد \\
\hline 6 & 5014 & Nasa'i & $\begin{array}{l}\text { Mentoring and } \\
\text { differences in Abdullah } \\
\text { bin Murrah and } \\
\text { Asysya'bi }\end{array}$ & الله بن مرة والثـتبـ وذكر الاختلاف على عبد \\
\hline 7 & 5015 & Nasa'i & $\begin{array}{l}\text { Mentoring and } \\
\text { differences in Abdullah } \\
\text { bin Murrah and } \\
\text { Asysya'bi }\end{array}$ & 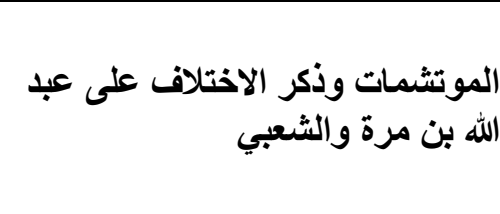 \\
\hline 8 & 5016 & Nasa'i & $\begin{array}{l}\text { Mentoring and } \\
\text { differences in Abdullah } \\
\text { bin Murrah and } \\
\text { Asysya'bi }\end{array}$ & الله بن مرة والثُتبي وذكر الاختلاف على عبد \\
\hline 9 & 2268 & $\begin{array}{l}\text { Ibnu } \\
\text { Majah }\end{array}$ & Hard rebuke in usury & التظليظ في الربا \\
\hline 10 & 933 & Ahmad & Musnad Ali bin Abu & ومن مسند علي بن أبي طالب رضي \\
\hline
\end{tabular}

${ }^{30}$ Ahmad bin Muhammad ibn Hanbal al-Syaibany, Al-Musnad Ibn al-Hambali (Lebanon: Dar al-Hadith, t.th), hadith no. 803 


\begin{tabular}{|c|c|c|c|c|}
\hline & & & $\begin{array}{l}\text { Thalib Radliyallahu } \\
\text { 'anhu }\end{array}$ & الله عنه \\
\hline 11 & 1065 & Ahmad & $\begin{array}{l}\text { Musnad Ali bin Abu } \\
\text { Thalib Radliyallahu } \\
\text { 'anhu }\end{array}$ & الله عنه مسند علي بن أبي طالب رضي \\
\hline 12 & 1222 & Ahmad & $\begin{array}{l}\text { Musnad Ali bin Abu } \\
\text { Thalib Radliyallahu } \\
\text { 'anhu }\end{array}$ & الله عنه مسند علي بن أبي طالب رضي \\
\hline 13 & 1294 & Ahmad & $\begin{array}{l}\text { Musnad Ali bin Abu } \\
\text { Thalib Radliyallahu } \\
\text { 'anhu }\end{array}$ & الله عنه مسند علي بن أبي طالب رضي \\
\hline 14 & 3539 & Ahmad & $\begin{array}{l}\text { Musnad Abdullah bin } \\
\text { Mas'ud Radliyallahu } \\
\text { ta'ala 'anhu }\end{array}$ & تعالى عند عبد الله بن مسعود رضي الله \\
\hline 15 & 3550 & Ahmad & $\begin{array}{l}\text { Musnad Abdullah bin } \\
\text { Mas'ud Radliyallahu } \\
\text { ta'ala 'anhu }\end{array}$ & تعالى عند عبد الله بن مسعود رضي الله \\
\hline 16 & 3618 & Ahmad & $\begin{array}{l}\text { Musnad Abdullah bin } \\
\text { Mas'ud Radliyallahu } \\
\text { ta'ala 'anhu }\end{array}$ & تعالى عند عبد الله بن مسعود رضي الله \\
\hline 17 & 3687 & Ahmad & $\begin{array}{l}\text { Musnad Abdullah bin } \\
\text { Mas'ud Radliyallahu } \\
\text { ta'ala 'anhu }\end{array}$ & تعالى عند عبد الله بن مسعود رضي الله \\
\hline 18 & 3881 & Ahmad & $\begin{array}{l}\text { Musnad Abdullah bin } \\
\text { Mas'ud Radliyallahu } \\
\text { ta'ala 'anhu }\end{array}$ & تعالى عند عبد الله بن مسعود رضي الله \\
\hline 19 & 4099 & Ahmad & $\begin{array}{l}\text { Musnad Abdullah bin } \\
\text { Mas'ud Radliyallahu } \\
\text { ta'ala 'anhu }\end{array}$ & تعالى عند عبد الله بن مسعود رضي الله \\
\hline 20 & 4196 & Ahmad & $\begin{array}{l}\text { Musnad Abdullah bin } \\
\text { Mas'ud Radliyallahu } \\
\text { ta'ala 'anhu }\end{array}$ & تعالى عنده عبد الله بن مسعود رضي الله \\
\hline 21 & 13744 & Ahmad & $\begin{array}{l}\text { Musnad Jabir bin } \\
\text { Abdullah Radliyallahu } \\
\text { ta'ala 'anhu }\end{array}$ & عنه جند جابر بن عبد الله رضي الله تعالى \\
\hline 22 & 2423 & Darimi & Usury eaters and donors & باب فى آكل الربا ومؤكله \\
\hline
\end{tabular}


While the hadith number 1222 in Ahmad Musnad, it will appear in the Book: Musnad ten companions who are guaranteed to enter heaven, Chapter: Musnad Ali bin Abu Talib Radliyallahu 'anhu, No. Hadith: 1222, the hadith as follows:

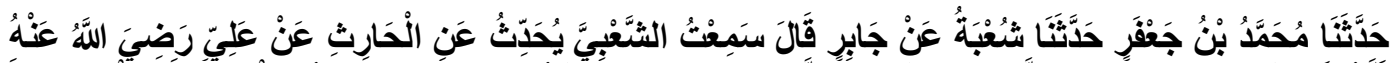

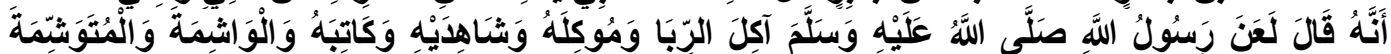

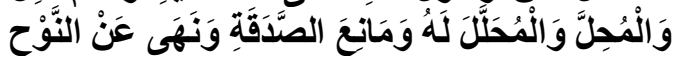

Meaning: Having told us Muhammad bin Ja'far had told us the Syu'bah of Jabir said; I heard Asy Sya'bi tell from Al Harith from Ali Radhiallah 'anhu, he said; "The Prophet sallallaahu alaihi wasallam cursed those who ate usury, people who fed with property of usury, two witnesses, women who tattooed and women who requested tattooing, al muhallil and al muhallal lahu, people who did not pay zakat, and he also forbade lamenting the corpse."( Narrated by Ahmad). ${ }^{31}$

Hadith Ahmad No. 1122 above is supported by 19 traditions from several histories. See the following table of the verses of the hadith of al-Tis'ah:

\begin{tabular}{|c|c|c|c|c|}
\hline No & $\begin{array}{c}\text { No } \\
\text { Hadith }\end{array}$ & $\begin{array}{l}\text { Narrato } \\
\text { rs }\end{array}$ & $\begin{array}{c}\text { Titles in the Book of } \\
\text { Hadith }\end{array}$ & $\begin{array}{c}\text { Text of the Arabic Text of } \\
\text { the Hadith Book }\end{array}$ \\
\hline 1 & 2994 & Muslim & $\begin{array}{l}\text { Usury eaters and donors } \\
\text { will be cursed }\end{array}$ & لعن آكل الربا ومؤكله \\
\hline 2 & 2995 & Muslim & $\begin{array}{l}\text { Usury eaters and donors } \\
\text { will be cursed }\end{array}$ & لعن آكل الربا ومؤكله \\
\hline 3 & 2895 & $\begin{array}{l}\text { Abu } \\
\text { Daud }\end{array}$ & $\begin{array}{l}\text { People who eat usury and } \\
\text { those who give it }\end{array}$ & في آكل الربا وموكله \\
\hline 4 & 1127 & $\begin{array}{l}\text { Tirmidz } \\
\mathrm{i}\end{array}$ & Eat usury & ما جاء في أكل الربا \\
\hline 5 & 5013 & Nasa'i & $\begin{array}{l}\text { Mentoring and differences } \\
\text { in Abdullah bin Murrah } \\
\text { and Asysya'bi }\end{array}$ & الله بن مرة والثتبي وذكر الاختلاف على عبد \\
\hline 6 & 5014 & Nasa'i & $\begin{array}{l}\text { Mentoring and differences } \\
\text { in Abdullah bin Murrah } \\
\text { and Asysya'bi }\end{array}$ & الله بن مرة والثتبـ وذكر الاختلاف على عبد \\
\hline 7 & 5015 & Nasa'i & $\begin{array}{l}\text { Mentoring and differences } \\
\text { in Abdullah bin Murrah }\end{array}$ & الله بن مرة والثُتبـي وذكر الاختلاف على عبد \\
\hline
\end{tabular}

${ }^{31}$ Ahmad bin Muhammad ibn Hanbal al-Syaibany, Al-Musnad Ibn al-Hambali (Lebanon: Dar al-Hadith, t.th), hadith no. 1222 


\begin{tabular}{|c|c|c|c|c|}
\hline & & & and Asysya'bi & \\
\hline 8 & 5016 & Nasa'i & $\begin{array}{l}\text { Mentoring and differences } \\
\text { in Abdullah bin Murrah } \\
\text { and Asysya'bi }\end{array}$ & الله بن مرة والثتبعي وذكر الاختلاف على عبد \\
\hline 9 & 2268 & $\begin{array}{l}\text { Ibnu } \\
\text { Majah }\end{array}$ & Hard rebuke in usury & التظليظ في الربا \\
\hline 10 & 1294 & Ahmad & $\begin{array}{l}\text { Musnad Ali bin Abu } \\
\text { Thalib Radliyallahu 'anhu }\end{array}$ & الله عنه مسند علي بن أبي طالب رضي \\
\hline 11 & 3539 & Ahmad & $\begin{array}{l}\text { Musnad Abdullah bin } \\
\text { Mas'ud Radliyallahu ta'ala } \\
\text { 'anhu }\end{array}$ & تعالى عنده عبد الله بن مسعود رضي الله \\
\hline 12 & 3550 & Ahmad & $\begin{array}{l}\text { Musnad Abdullah bin } \\
\text { Mas'ud Radliyallahu ta'ala } \\
\text { 'anhu }\end{array}$ & تعالى عنده عبد الله بن مسعود رضي الله \\
\hline 13 & 3618 & Ahmad & $\begin{array}{l}\text { Musnad Abdullah bin } \\
\text { Mas'ud Radliyallahu ta'ala } \\
\text { 'anhu }\end{array}$ & تعالى عنده عبد الله بن مسعود رضي الله \\
\hline 14 & 3687 & Ahmad & $\begin{array}{l}\text { Musnad Abdullah bin } \\
\text { Mas'ud Radliyallahu ta'ala } \\
\text { 'anhu }\end{array}$ & تعالى عنده عبد الله بن مسعود رضي الله \\
\hline 15 & 3881 & Ahmad & $\begin{array}{l}\text { Musnad Abdullah bin } \\
\text { Mas'ud Radliyallahu ta'ala } \\
\text { 'anhu }\end{array}$ & تعالى عنده عبد الله بن مسعود رضي الله \\
\hline 16 & 4099 & Ahmad & $\begin{array}{l}\text { Musnad Abdullah bin } \\
\text { Mas'ud Radliyallahu ta'ala } \\
\text { 'anhu }\end{array}$ & تعالى عنده عبد الله بن مسعود رضي الله \\
\hline 17 & 4196 & Ahmad & $\begin{array}{l}\text { Musnad Abdullah bin } \\
\text { Mas'ud Radliyallahu ta'ala } \\
\text { 'anhu }\end{array}$ & تعالى عنده عبد الله بن مسعود رضي الله \\
\hline 18 & 13744 & Ahmad & $\begin{array}{l}\text { Musnad Jabir bin } \\
\text { Abdullah Radliyallahu } \\
\text { ta'ala 'anhu }\end{array}$ & عنه مسند جابر بن عبد الله رضي الله تعالى \\
\hline 19 & 2423 & Darimi & Usury eaters and donors & باب فى آكل الربا ومؤكله \\
\hline
\end{tabular}

While the hadith number 1294 in Ahmad Musnad, it will appear in the Book: The ten musnad are guaranteed to enter Paradise, Chapter: Musnad Ali bin Abu Talib Radliyallahu 'anhu, No. Hadist: 1294, the hadith as follows: 


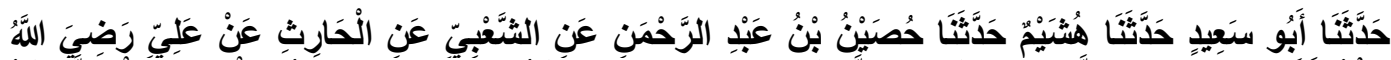

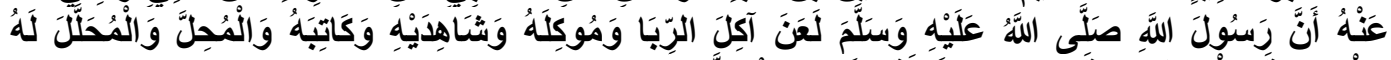

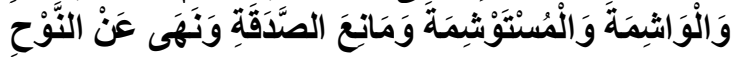
Meaning: Having told us Abu Sa'id had told us Husyaim had told us Hushain bin Abdurrahman from Ash Sya'bi of Al Harith from Ali Radhiallah 'anhu that the Messenger of Allah sallallaahu' alaihi wasallam cursed the person who ate usury, the person who gave eat with treasure of usury, two witnesses, (and he cursed) al muhallil and al muhallal lahu, women who tattooed and women asked to be tattooed, people who did not want to pay zakat, and he also forbade mourning corpses. "( Narrated by Ahmad). ${ }^{32}$

Hadith Ahmad No. 1294 above is supported by 14 traditions from several narrations. See the following table of the verses of the hadith of al-Tis'ah:

\begin{tabular}{|c|c|c|c|c|}
\hline No & $\begin{array}{c}\text { No } \\
\text { Hadith }\end{array}$ & $\begin{array}{l}\text { Narrato } \\
\text { rs }\end{array}$ & $\begin{array}{c}\text { Titles in the Book of } \\
\text { Hadith }\end{array}$ & $\begin{array}{c}\text { Text of the Arabic Text of } \\
\text { the Hadith Book }\end{array}$ \\
\hline 1 & 2994 & Muslim & $\begin{array}{l}\text { Usury eaters and donors } \\
\text { will be cursed }\end{array}$ & لعن آكل الربا ومؤكله \\
\hline 2 & 2995 & Muslim & $\begin{array}{l}\text { Usury eaters and donors } \\
\text { will be cursed }\end{array}$ & لعن آكل الربا ومؤكله \\
\hline 3 & 2895 & $\begin{array}{l}\text { Abu } \\
\text { Daud }\end{array}$ & $\begin{array}{l}\text { People who eat usury and } \\
\text { those who give it }\end{array}$ & في آكل الربا وموكله \\
\hline 4 & 1127 & Tirmidzi & Eat usury & مـا جاء في أكل الربا \\
\hline 5 & 5014 & Nasa'i & $\begin{array}{l}\text { Mentoring and } \\
\text { differences in Abdullah } \\
\text { bin Murrah and } \\
\text { Asysya'bi }\end{array}$ & 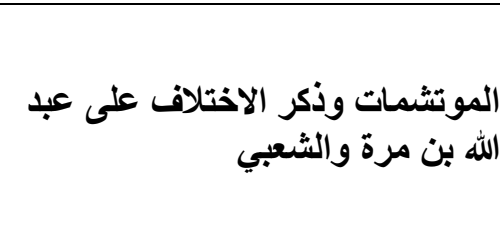 \\
\hline 6 & 5015 & Nasa'i & $\begin{array}{l}\text { Mentoring and } \\
\text { differences in Abdullah } \\
\text { bin Murrah and } \\
\text { Asysya'bi }\end{array}$ & 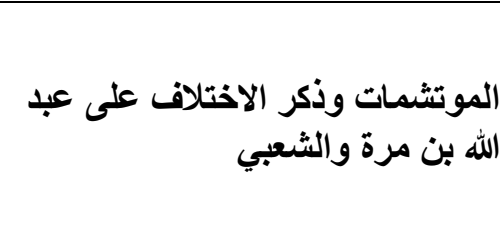 \\
\hline 7 & 5016 & Nasa'i & $\begin{array}{l}\text { Mentoring and } \\
\text { differences in Abdullah } \\
\text { bin Murrah and } \\
\text { Asysya'bi }\end{array}$ & الله بن مرة والثُبـي وذكر الاختلاف على عبد \\
\hline 8 & 2268 & Ibnu & Hard rebuke in usury & التظليظ في الربا \\
\hline
\end{tabular}

${ }^{32}$ Ahmad bin Muhammad ibn Hanbal al-Syaibany, Al-Musnad Ibn al-Hambali (Lebanon: Dar al-Hadith, t.th), hadith no. 1294 


\begin{tabular}{|c|c|c|c|c|}
\hline & & Majah & & \\
\hline 9 & 3539 & Ahmad & $\begin{array}{l}\text { Musnad Abdullah bin } \\
\text { Mas'ud Radliyallahu } \\
\text { ta'ala 'anhu }\end{array}$ & تعالى عنده عبد الله بن مسعود رضي الله \\
\hline 10 & 3550 & Ahmad & $\begin{array}{l}\text { Musnad Abdullah bin } \\
\text { Mas'ud Radliyallahu } \\
\text { ta'ala 'anhu }\end{array}$ & تعالى عنده الله بن مسعود رضي الله \\
\hline 11 & 3618 & Ahmad & $\begin{array}{l}\text { Musnad Abdullah bin } \\
\text { Mas'ud Radliyallahu } \\
\text { ta'ala 'anhu }\end{array}$ & تعالى عنــ عبد الله بن مسعود رضي الله \\
\hline 12 & 4099 & Ahmad & $\begin{array}{l}\text { Musnad Abdullah bin } \\
\text { Mas'ud Radliyallahu } \\
\text { ta'ala 'anhu }\end{array}$ & تعالى عنــ عبد الله بن مسعود رضي الله \\
\hline 13 & 13744 & Ahmad & $\begin{array}{l}\text { Musnad Jabir bin } \\
\text { Abdullah Radliyallahu } \\
\text { ta'ala 'anhu }\end{array}$ & عنه جند جابر بن عبد الله رضي الله تعالى \\
\hline 14 & 2423 & Darimi & Usury eaters and donors & باب فى آكل الربا ومؤكله \\
\hline
\end{tabular}

Whereas the hadith number 3539 in the Musnad Ahmad, it will appear in itab: Musnad companions who have narrated many hadith, Chapter: Musnad Abdullah bin Mas'ud Radliyallahu ta'ala 'anhu, No. Hadist: 3539, the hadith as follows:

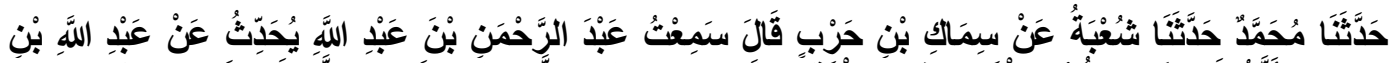

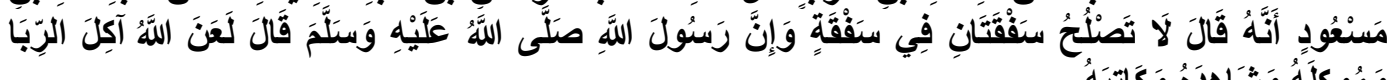

Meaning: Having told us Muhammad had told us Shu'bah from Simak bin Harb he said; I heard Abdurrahman bin Abdullah tell from Abdullah bin Mas'ud that he said; Invalid there are two contracts (buying and selling) in one contract, in fact the Prophet sallallaahu 'alaihi wasallam said: "Allah cursed the eaters of usury, who gave him, witnesses of the usury contract and the person who wrote it." (Narrated by Ahmad). ${ }^{33}$

Hadith Ahmad No. 3539 above is supported by 17 traditions from several histories. See the following table of the verses of the hadith of al-Tis'ah:

${ }^{33}$ Ahmad bin Muhammad ibn Hanbal al-Syaibany, Al-Musnad Ibn al-Hambali (Lebanon: Dar al-Hadith, t.th), hadith no 3539 


\begin{tabular}{|c|c|c|c|c|}
\hline No & $\begin{array}{c}\text { No } \\
\text { Hadith }\end{array}$ & $\begin{array}{l}\text { Narrato } \\
\text { rs }\end{array}$ & $\begin{array}{c}\text { Titles in the Book of } \\
\text { Hadith }\end{array}$ & $\begin{array}{c}\text { Text of the Arabic Text of } \\
\text { the Hadith Book }\end{array}$ \\
\hline 1 & 2994 & Muslim & $\begin{array}{l}\text { Usury eaters and donors } \\
\text { will be cursed }\end{array}$ & لعن آكل الربا ومؤكله \\
\hline 2 & 2995 & Muslim & $\begin{array}{l}\text { Usury eaters and donors } \\
\text { will be cursed }\end{array}$ & لعن آكل الربا ومؤكله \\
\hline 3 & 2895 & $\begin{array}{l}\text { Abu } \\
\text { Daud }\end{array}$ & $\begin{array}{l}\text { People who eat usury and } \\
\text { those who give it }\end{array}$ & في آكل الربا وموكله \\
\hline 4 & 1127 & Tirmidzi & Eat usury & ما جاء في أكل الربا \\
\hline 5 & 5013 & Nasa'i & $\begin{array}{l}\text { Mentoring and } \\
\text { differences in Abdullah } \\
\text { bin Murrah and } \\
\text { Asysya'bi }\end{array}$ & الله بن مرة والثـتبـ وذكر الاختلاف على عبد \\
\hline 6 & 5014 & Nasa'i & $\begin{array}{l}\text { Mentoring and } \\
\text { differences in Abdullah } \\
\text { bin Murrah and } \\
\text { Asysya'bi }\end{array}$ & الله بن مرة والثمات وذكر الاختلاف على عبد \\
\hline 7 & 5015 & Nasa'i & $\begin{array}{l}\text { Mentoring and } \\
\text { differences in Abdullah } \\
\text { bin Murrah and } \\
\text { Asysya'bi }\end{array}$ & الله بن مرة واتثمات وذكر الاختلاف على عبد \\
\hline 8 & 5016 & Nasa'i & $\begin{array}{l}\text { Mentoring and } \\
\text { differences in Abdullah } \\
\text { bin Murrah and } \\
\text { Asysya'bi }\end{array}$ & الله بن مرة والثُتبي وذكر الاختلاف على عبد \\
\hline 9 & 2268 & $\begin{array}{l}\text { Ibnu } \\
\text { Majah }\end{array}$ & Hard rebuke in usury & التظليظ في الربا \\
\hline 10 & 3550 & Ahmad & $\begin{array}{l}\text { Musnad Abdullah bin } \\
\text { Mas'ud Radliyallahu } \\
\text { ta'ala 'anhu }\end{array}$ & تعالى عنده عبد الله بن مسعود رضي الله \\
\hline 11 & 3618 & Ahmad & $\begin{array}{l}\text { Musnad Abdullah bin } \\
\text { Mas'ud Radliyallahu } \\
\text { ta'ala 'anhu }\end{array}$ & تعالى عنده عبد الله بن مسعود رضي الله \\
\hline 12 & 3687 & Ahmad & $\begin{array}{l}\text { Musnad Abdullah bin } \\
\text { Mas'ud Radliyallahu } \\
\text { ta'ala 'anhu }\end{array}$ & تعالى عنده الله بن مسعود رضي الله \\
\hline 13 & 3881 & Ahmad & $\begin{array}{l}\text { Musnad Abdullah bin } \\
\text { Mas'ud Radliyallahu }\end{array}$ & تعالى عنده عبد الله بن مسعود رضي الله \\
\hline
\end{tabular}




\begin{tabular}{|c|c|c|c|c|}
\hline & & & ta'ala 'anhu & \\
\hline 14 & 4099 & Ahmad & $\begin{array}{l}\text { Musnad Abdullah bin } \\
\text { Mas'ud Radliyallahu } \\
\text { ta'ala 'anhu }\end{array}$ & تعالى عند عبد الله بن مسعود رضي الله \\
\hline 15 & 4196 & Ahmad & $\begin{array}{l}\text { Musnad Abdullah bin } \\
\text { Mas'ud Radliyallahu } \\
\text { ta'ala 'anhu }\end{array}$ & تعالى عنــ عبد الله بن مسعود رضي الله \\
\hline 16 & 13744 & Ahmad & $\begin{array}{l}\text { Musnad Jabir bin } \\
\text { Abdullah Radliyallahu } \\
\text { ta'ala 'anhu }\end{array}$ & عنه جند جابر بن عبد الله رضي الله تعالى \\
\hline 17 & 2423 & Darimi & Usury eaters and donors & باب فى آكل الربا ومؤكله \\
\hline
\end{tabular}

While the hadith number 3567 in Ahmad Musnad, it will appear in the Book: Musnad companions who have narrated many hadith, Chapter: Musnad Abdullah bin Mas'ud Radliyallahu ta'ala 'anhu, No. Hadist: 3567, the traditions are as follows:

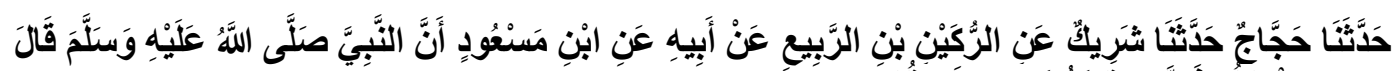

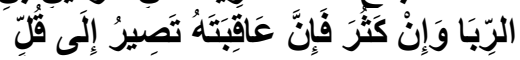

Meaning: Having told us Hajjaj had told us Syarik of Ar Rukain bin Ar Rabi 'from his father from Ibn Mas'ud that the Prophet sallallaahu' alaihi wasallam said: "The treasure of riba though many will eventually become a little." (Narrated by Ahmad). ${ }^{34}$

Hadith Ahmad No. 3567 above is supported by 1 hadith from several histories. See the following table of the verses of the hadith of al-Tis'ah:

\begin{tabular}{|c|c|l|l|c|}
\hline No & $\begin{array}{c}\text { No } \\
\text { Hadith }\end{array}$ & $\begin{array}{l}\text { Narrato } \\
\text { rs }\end{array}$ & $\begin{array}{c}\text { Titles in the Book of } \\
\text { Hadith }\end{array}$ & $\begin{array}{c}\text { Text of the Arabic Text of } \\
\text { the Hadith Book }\end{array}$ \\
\hline 1 & 3822 & Ahmad & $\begin{array}{l}\text { Musnad Abdullah bin } \\
\text { Mas'ud Radliyallahu } \\
\text { ta'ala 'anhu }\end{array}$ & تعالى عند الله بن مسعود رضي الله \\
\hline
\end{tabular}

While the hadith number 13744 in Ahmad Musnad, it will appear in the Book: The rest of the Musnad companions who have narrated many hadith, Chapter: Musnad Jabir bin Abdullah Radliyallahu ta'ala 'anhu, No. Hadith: 13744, the hadith as follows:

${ }^{34}$ Ahmad bin Muhammad ibn Hanbal al-Syaibany, Al-Musnad Ibn al-Hambali (Lebanon: Dar al-Hadith, t.th), hadith no. 3567 


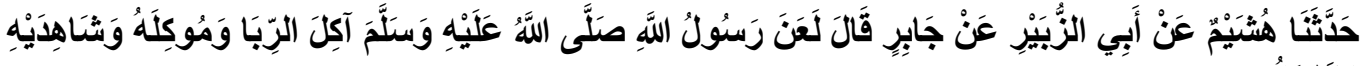

Meaning: Having told us Husyaim of Abu Az Zubair of Jabir said; The Prophet sallallaahu 'alaihi wasallam cursed the one who ate usury, who fed with usury, two witnesses and the author (Narrated by Ahmad). ${ }^{35}$

Hadith Ahmad No. 13744 above there is no hadith in al-Tis'ah's pole which supports it.

\section{Conclusion}

The results of the study can be concluded that in the book mausu'ah alhadis al-Nabawiyah, from the perceptive Ahmad musnad, the hadith related to the property of usury, the author found there are 6 traditions from ahmad's history. The hadith is the hadith number 803 in the book Musnad Ahmad, it will appear in the Book: Musnad of ten companions who are guaranteed to enter heaven, Chapter: Musnad Ali bin Abu Talib Radliyallahu 'anhu, No. Hadith: 803, the hadith is supported by 22 traditions from several narrations. While the hadith number 1222 in Ahmad Musnad, it will appear in the Book: Musnad ten companions who are guaranteed to enter heaven, Chapter: Musnad Ali bin Abu Talib Radliyallahu 'anhu, No. Hadith: 1222, the hadith is supported by 19 traditions from several histories. While the hadith number 1294 in Ahmad Musnad, it will appear in the Book: The ten companions Musnad are guaranteed to enter Paradise, Chapter: Musnad Ali bin Abu Talib Radliyallahu 'anhu, No. Hadith: 1294, the hadith is supported by 14 traditions from several narrations. Whereas the hadith number 3539 in the Musnad Ahmad, it will appear in itab: Musnad companions who have narrated many hadith, Chapter: Musnad Abdullah bin Mas'ud Radliyallahu ta'ala 'anhu, No. Hadist: 3539, the hadith is supported by 17 traditions from several narrations. While the hadith number 3567 in Ahmad Musnad, it will appear in the Book: Musnad companions who have narrated many hadith, Chapter: Musnad Abdullah bin Mas'ud Radliyallahu ta'ala 'anhu, No. Hadith: 3567 , the hadith is supported by 1 hadith from several histories. While the

${ }^{35}$ Ahmad bin Muhammad ibn Hanbal al-Syaibany, Al-Musnad Ibn al-Hambali (Lebanon: Dar al-Hadith, t.th), hadith no. 13744 
hadith number 13744 in Ahmad Musnad, it will appear in the Book: Remaining Musnad companions who have narrated many hadith, Chapter: Musnad Jabir bin Abdullah Radliyallahu ta'ala 'anhu, No. Hadith: 13744, the hadith there is no hadith in al-Tis'ah's support. So from the hadith it can be drawn the understanding that Allah cursed the eaters of usury, the person who fed with the property of usury, the witness of the contract of usury and the person who wrote it. A lot of usury though in the end will be a little.

\section{REFERENCE}

Abdullah al-Mushlih and Shalah ash-Shawi, Jurisprudence in Islamic Financial Economics (Jakarta: Darul Haq, 2014)

Abdullah Malik ibn Anas ibn Malik ibn Abi Amir ibn Amr ibn al-Haris ibn Gaiman ibn Husail ibn Amr ibn al-Haris al-Asbahi al-Madani, (t.th), AlMua'tha 'Imam Malik (Beirut: Dar Fikri)

Abdurrahman al-Jaziri, Kitab al-fiqh 'ala al-Mazahib al-Arba'ah, (Beirut: dar alFikr, 2012)

Abdurrahman ibn 'Abdirahman ibn al-Fadhl ibn Bahram ibn' Abdis Shamad, (t.th), Al-Sunan Al-Darimi (Cairo Egypt: Maktabah alam)

Abu 'Abdillah Muhammad bin Yazid bin' Abdillah bin Majah al-Qazwini, (t.th), Al-Sunan Ibn Majah (Egypt: Maktabah al-Sunnah)

Abu 'Abdirrahman ahmad bin su'aib bin ali bin bahr bin sinan ibn din-an-Nasai al-Kurasani, (t.th), Al-Sunan al-Nasa'i (Cairo: Dar Ilmi)

Abu 'Isa Muhammad bin a isa bin surrah al-Turmudzi Ibn Musa Ibn Adh-Dhahak Al-Sulami Al-Bughi Al-Tirmidhi, Al-Sunan Al-Tirmizi (Lebanon: Dar alHadith, t.th)

Abu Abdullah Muhammad ibn Ismail Al-Bukhari bin Ibrahim bin Al-Mughirah bin Bardizbah, Imam al-Bukhari, Sahih Bukhari (Bairut: Darul Ibn Kathir al-Yammah, t.th)

Abu Sura'i Abdul Hadi, Bunga Bank In Islam, transfer language M. Thalib, (Surabaya: al-Ikhlas, 2013)

Abu Zuhry and Ahmad Sabiq, Law of Sale and Purchase of Credit, see wibesite online at https://abuzuhriy.wordpress.com/2010/10/03/hukum-jual-belikredit/. Accessed on September 21, 2018 
Abul Husain Muslim bin al-Hajjaj al-Naisaburi, Imam Muslim, Shahih Muslim (Beirut: Dar Ibn Kathir, t.th)

Ahmad bin Muhammad ibn Hanbal al-Syaibany, Al-Musnad Ibn al-Hambali (Lebanon: Dar al-Hadith, t.th)

Ahmad Munawir, Dictionary of al-Munawir Arabic-Indonesian, (Yogyakarta: PP. Al-Munawwir, 2013)

Boy Syamsul Bakhri, Islamic Economic System in Comparison (Al-Hikmah Journal Vol. 8, No. 1, April, 2011, ISSN 1412-5382)

Bungin Burhan, Qualitative Research Methodology, (Jakarta: Raja Grafindo Persada, 2014)

Chairuman Pasaribu and Suhrawardi K. Lubis, Agreement Law in Islam, (Jakarta: Sinar Grafika, 2014)

Dedy Mulyana, Qualitative Research Methodology, (Bandung: Youth Rosdakarya, 2015)

RI Ministry of Religion, Al-Qur'an and Translation (Semarang: Toha Putra, 2015).

Endang Soetari, Science of Hadith Study of History and Trustworthiness (Bandung: CV. Mimbar Library, 2017)

Hadari Nawawi, Social Research Methods, (Yogyakarta: Gajah Mada University Press, 2016)

Hamidi, Qualitative research method, (Malang: Muhammadiyah University Malang, 2014)

HB Sutopo, Introduction to Qualitative Research, (Surakarta: Sebelas Maret University Press, 2014)

Imam Suprayogo and Tobroni, Social-Religion Research Methodology, (Bandung: Teenager Rosdakarya, 2012)

Iskandar, Qualitative Research Methods: Applications for Educational Research, Law, Economics \& Management, Social Sciences, Humanities, Politics, Religion and Philosophy, (Jakarta: Gaung Persada, 2010)

Khoiruddin Nasution, Riba and Polygamy, A Study of Muhammad Abduh's Thought, (Yogyakarta: Student Library in collaboration with ACAdeMIA, 2016) 
Lexy J Moleong, Qualitative Research Methodology, (Bandung: Teenager Rosdakarya, 2011)

M Al-Maliki Alawi, Ushul Hadith Science (Yogyakarta: Offset Student Library, 2012)

M. Abdurrahman, Hadith Book Study (Yogyakarta: Teras, 2013)

M. Agus Shalahudin, Ulumul Hadith (Bandung,: CV Pustaka Setia, 2013)

Muhammad A'jal Al-khatib, Principles of the Science of Hadith, (Jakarta: Gaya media pratama, 2014)

Muhammad Nazir, Research Methodology, (Jakata: Ghalia Indonesia, 2015)

Muslims, Sharia Review of Credit Purchases, see wibesite online https://muslim.or.id/20961-view-syari-terhadap-jual-beli-kredit.html. Accessed on September 20, 2018

Nawir Yuslem, Kitab Induk Hadis (Jakarta: Hijir Main Library, 2016)

Neong Muhajir, Qualitative Research Methodology, (Yogyakarta: Rake Sarasin, 2014)

Nurhadi, Engagement Legal Analysis Contract Agreement for Murabahah Bil Wakalah Financing Number 090 / Mrbh / Pkb / V / 2016 Syari'ah Bank Rakyat Indonesia (Thesis: Masters Program (S2) Postgraduate Program in Riau Islamic University Pekanbaru, 2016)

Nurhadi, Hilah Syariah Conventional Bank Credit (Maqashid Buy and Sell Credit (Another Contract of Contract)), Journal of Islamic Law, Vol. XVII No. December 2, 2017

Subhi al-Shalih, Discussing the Science of Hadith, (Jakarta: Paradise Library, 2017)

Abul A'la al-Maududi, Talk about Bank Interest and Usury (Jakarta: Mega Media, 2014) 